\title{
Pathways to Global Democracy? Escaping the Statist Imaginary
}

\author{
Adrian Little, University of Melbourne \\ Kate Macdonald, University of Melbourne ${ }^{1}$
}

\section{Introduction}

The literature on global democracy has often been accused of trading in institutional fantasies, divorced from the constraints of the real political world. Miller for instance has criticised the literature on global democracy for asking "only about where democracy is needed ... without considering whether it is actually possible to conjure the necessary democratic body into existence (or if this is possible, in a formal sense at least, how it is likely to perform)." ${ }^{2}$ Even supporters of aspects of normative democratic projects often express scepticism of this kind, Buchanan and Keohane for example claiming that: “... the social and political conditions for democracy are not met at the global level and there is no reason to think that they will be in the foreseeable future". ${ }^{3}$

Scholars of global democracy are taking such practical questions about the necessary social foundations for a global democratic project increasingly seriously. ${ }^{4}$ Attention is turning both to the analysis of existing social conditions to assess the extent to which democratic institutions might already be feasible, and to questions about the social forces and mechanisms that could at least move global institutions in a more democratic direction.

In exploring these questions, both sceptics and advocates of global democratic reform frequently build their arguments with reference to democratic institutions and underlying social conditions within nation states. Critiques of global democracy are often focused on identification of the social conditions necessary to sustain democratic practices at the national level, followed by claims that these conditions are absent at the global level. ${ }^{5}$ Conversely,

\footnotetext{
${ }^{1}$ We would like to thank all the colleagues who have offered us helpful criticisms and suggestions on earlier versions of the paper. In particular, we would like to thank participants in the Global Demos Conference, organised by Mathias Koenig-Archibugi and Christian List at the LSE in July 2011, members of the Melbourne Political Theory Reading Group, and the anonymous referees from this journal.

${ }^{2}$ D. Miller, 'Democracy’s Domain', Philosophy \& Public Affairs 37 (2009), p.228

${ }^{3}$ A. Buchanan, \& Robert O. Keohane, 'The Legitimacy of Global Governance Institutions', Ethics \& International Affairs, 20 (2006), pp. 405-37.

${ }^{4}$ M. Koenig-Archibugi, 'Is Global democracy Possible? ', European Journal of International Relations, 7 (2010), pp. 519-42, D. Archibugi, M. Koenig-Archibugi and R. Marchetti, Global Democracy: Normative and Empirical Perspectives (Cambridge Cambridge University Press, 2011). Until very recently, much of the literature on global democracy has been preoccupied with debates about whether global democracy is desirable, and if so, what models of global democracy should be supported. See for example J. S. Dryzek, 'Transnational Democracy', Journal of Political Philosophy, 7 (1999), pp. 30-51, A. Kuper, Democracy Beyond Borders: Justice and Representation in Global Institutions (Oxford: Oxford University Press, 2004), R. Marchetti, Global Democracy: For and Against: Ethical Theory, Institutional Design and Social Struggles (Abingdon: Routledge, 2008).

${ }^{5}$ R. A. Dahl, Democracy and its critics (New Haven: Yale University Press, 1989), pp. viii, 397, A. Buchanan, \& Robert O. Keohane, 'The Legitimacy of Global Governance Institutions', Ethics \& International Affairs, 20 (2006), pp. 405-37, D. Miller, 'Democracy’s Domain'.
} 
defenders of global democracy invoke evidence from democratization processes within nation states to argue that global democracy, at the very least, is not impossible. ${ }^{6}$

Such debates about the material prospects of democratizing global governance arrangements have been framed in a couple of subtly but importantly distinct ways. Sometimes the question has been focused on whether 'global democracy', of a form and a quality familiar from the nation state, might possibly be attained in the future, given what we know about 'necessary' conditions for the emergence of democracy in national contexts. ${ }^{7}$ More often, however, the question addresses the immediate and more practical issue of whether the prospects for meaningful democratization are sufficiently feasible that it is worth pursuing at all. While it is broadly accepted that some incremental democratic reform may be feasible, there is a widespread view in the literature that the degree and impact of such democratic change is insufficient to warrant significant investment of energy by transformative agents concerned about the legitimacy of global governance, especially given the possibility of pursuing other types of political reform.

To take two prominent examples, Buchanan and Keohane argue that it is not feasible under prevailing global social conditions to achieve "democracy worth aspiring to", concluding that we should therefore be "more willing to explore an alternative conception of [the] legitimacy [of global governance institutions]”. 8 Similarly, David Miller claims that only 'weak' forms of democracy ('elitist, inegalitarian and narrow in scope') are likely to be feasible at the global level, arguing therefore that the pursuit of global democratization 'will distract our attention from more urgent tasks'. ${ }^{9}$ In other words, these commentators argue that the practical pursuit of meaningful democratization is sufficiently constrained by structural features of the global order to imply that democratic principles are simply the wrong kinds of standards for us to apply in processes of institutional critique and transformation surrounding emerging systems of global governance.

This article engages critically with this emergent debate about the prospects for democratic transformation. The main objective is to show how analysis of the potential for meaningful strengthening of global democratic practice is currently being distorted by an overly narrow and state-centric analytical lens. This lens structures and frames analysis at two levels, in subtle yet pervasive ways. First, it conditions analysis of political institutions and other practices that constitute 'democracy', with these usually being imagined to resemble "well functioning” national democracies. Second, it frames analysis of the underlying social

\footnotetext{
${ }^{6}$ M. Koenig-Archibugi, 'Is Global democracy Possible? ', pp. 519-42. This is a somewhat subtle point, and of course there are important exceptions. M. Goodhart, 'Human Rights and Global Democracy', Ethics and International Affairs, 22 (2008), p. 401, for example, is explicit in critiquing a statist view of democracy. Similarly, D. Held, Democracy and the Global Order: From the Modern State to Cosmopolitan Governance (Cambridge: Polity Press, 1995) is very explicit in critiquing state-centric assumptions, and pointing to the need for institutional models that fall outside this model. Nonetheless, most concrete reform proposals he outlines resemble familiar state centred institutional forms in important respects, thereby tending in practice to reinforce rather than challenge this statist tendency in the literature.

${ }^{7}$ See for example M. Koenig-Archibugi, 'Is Global democracy Possible? ', European Journal of International Relations, 7 (2010), pp. 519-42..

${ }^{8}$ A. Buchanan, \& Robert O. Keohane, 'The Legitimacy of Global Governance Institutions', Ethics \& International Affairs, 20 (2006), p.417

${ }^{9}$ D. Miller, 'Against Global Democracy', in K. Breen and S. O'Neill (eds.) After the Nation: Critical Reflections on Post-Nationalism (Basingstoke: Palgrave Macmillan (2010), p.148
} 
conditions within which these democratic practices are able to exist; ${ }^{10}$ again, these are usually imagined to accord with a highly idealised account of existing national democratic societies. ${ }^{11}$ This lens therefore importantly shapes and constrains how analysis of political institutions and social conditions are imagined, relevant variables categorised, and evidence deployed.

We argue that this mode of thinking about analogies between national and global democracy is flawed in important ways: it distorts our assessments of the prospects for the emergence of global democratic practices; it misleads us about the possible ends of global democratic transformation; it neglects nascent forms of democracy that are already emerging at the global level; and it fails to generate useful lessons regarding how democratic norms might best be promoted beyond the boundaries of the state.

First, in Part I, we explain how the progress of global democratic institution-building can be assessed with reference to core democratic values rather than specific institutions, enabling us to assess the feasibility of promoting global democratization without making institutionally specific or overly idealised assumptions about what global democratic institutions might look like. In Part II, we show how the statist ontology embraced by many global democratic sceptics encourages them to assess emerging global democratic practices with reference to highly idealised accounts of national democratic institutions, thereby misunderstanding the democratic significance of emerging practices. We suggest that if advocates of global democracy are to derive useful lessons from struggles to create and sustain democracy within nation states, a much less idealised and institutionally prescriptive view of democratic practices is required.

In Part III, we argue that much existing analysis also misconceptualises the social conditions underpinning democratic practices. While it is useful to identify relevant characteristics of established democratic societies (such as configurations of power, interest, value and identity), many established analyses often fail to appreciate both the diversity of ways in which these conditions can interact in providing a motivational basis for social actors to accept democratic authority, and the diversity of ways in which flawed yet meaningful democratic practices can be built around prevailing social obstacles within a given context.

Finally, in part IV, we examine two case studies, from the national and the global level, to demonstrate how 'structural' features of the contemporary global order do not present 'knock-out obstacles' to meaningful democratic change, as a number of authors have alleged. Rather, we argue, the success with which democratic practices can be established and sustained depends importantly on how effectively social actors mobilise democratic agency to transform or work around unfavourable structural conditions.

\footnotetext{
${ }^{10}$ A. Buchanan, \& Robert O. Keohane, 'The Legitimacy of Global Governance Institutions', pp. 405-37, C. List and M. Koenig-Archibugi, 'Can There Be a Global Demos? An Agency-Based Approach ', Philosophy and Public Affairs, 38 (2010), pp. 76-110.

11 This distinction is often made with reference to the kratos and demos. We prefer not to use these terms here. The kratos invokes and implies many of the state-like institutional assumptions that we critique in Part II. The demos - understood narrowly as a ‘collection of individuals' (List and Koenig-Archibugi, 'Can There Be a Global Demos? An Agency-Based Approach ') is too narrow a concept for grasping the relevant features of the social foundations that enable and constrain the emergence and sustainability of democratic global institutions. To understand the relevant "qualities and relationships" characterising a demos (in the words of Miller, 'Democracy’s Domain'), it is necessary to analyse broader features of the social order in which these individuals and their relationships are constituted, as we do in Part III.
} 
This paints a picture of prospects for meaningful democratic social transformation at the global level that is potentially much more optimistic than many existing accounts, because it focuses on democratizing processes rather than fully formed models of democracy. However, this optimism is grounded in an underlying scepticism about the extent to which we can ever realistically expect 'democratic institutions' to embody idealised democratic values of public control and equality. We conclude that arguments focused on an incremental expansion of democratic practices should be judged in comparative or relational terms rather than the debate on global democracy being carried out in terms of a transcendental model of wholesale systemic change.

\section{Concepts of 'global democracy': democratic values and practices}

Before embarking more systematically on our critique of global democratic scepticism, we need to clarify some conceptual questions about how democratic institution building can best be understood and assessed.

In the everyday vernacular, the term 'democracy' is commonly understood as a specific set of institutional practices. This concept of democracy usually accommodates multiple institutional 'models' of democracy, each comprised of some set of familiar institutional forms such as elections, public deliberation, direct citizen participation, and so on. From this perspective, debate about the feasibility of advancing global democracy should be simply concerned with whether these familiar institutions and practices could be extended in some form to a global 'scale'. As will become clear in the following sections, however, this straightforward, institutionally specific conception of democracy is poorly suited for our purposes, since the simple equation of democracy with specific institutions familiar from national democratic histories is a central assumption we wish to challenge.

Moreover, such 'common sense' understandings of democracy are often bound up with a highly idealised view of the extent to which actually-existing democratic institutions can fulfil the democratic values to which they aspire. On such a view, extremely high compliance with democratic principles is required before democratic language can properly be applied to a given set of social practices. This way of thinking about democracy is poorly suited to our interest in analysing more 'non-ideal' forms of progressive democratization at the global level, where a threshold of what would generally be recognised as 'Democracy' has not been reached. ${ }^{12}$ Instead, the kind of concept required to appraise the democratic character of emerging institutions must be built on what Amartya Sen has described as 'comparative' rather than 'transcendental' principles. Such a concept focuses not on what is required for the full realization of specified normative principles, but rather on the capacity to rank alternative societal arrangements from the perspective of the normative principles in question. ${ }^{13}$

As we discuss further in the following section of the paper, the language of democracy has become intimately tied up with concepts of democracy that embody both institutionally specific and idealised assumptions of the kinds just described. To help separate our

\footnotetext{
12 The notion of a 'threshold' where a set of practices or institutions embodying democratic values can properly be called 'Democracy' is often invoked, though rarely theorized explicitly. See for example M. KoenigArchibugi, 'Is Global democracy Possible? ', European Journal of International Relations, 7 (2010), p.3, and J. Tallberg and A. Uhlin, 'Civil Society and Global Democracy: An Assessment', in D. Archibugi, M. KoenigArchibugi and R. Marchetti (eds.) Global Democracy: Normative and Empirical Perspectives (Cambridge Cambridge University Press, 2011), p.227

${ }^{13}$ A. Sen, 'What do we want from a theory of justice?', The Journal of Philosophy, 103 (2006), p.216
} 
conceptual analysis from assumptions of these kinds, we therefore employ the language of 'democratic practices' rather than 'democracy'. As we use the term, democratic practices can be understood as a range of initiatives that are motivated by fundamental democratic principles of political control and political equality, ${ }^{14}$ and that in practice contribute something meaningful to promoting these values.

These fundamental values of political equality and political control are clearly linked, so that to be 'democratic' in character, institutions must support in some way the exercise of political control on the basis of equality between individuals. ${ }^{15}$ Nevertheless, these values are separable in assessing whether particular initiatives are contributing to a more or less democratic set of arrangements in a particular context. To the extent that institutions contribute to promoting the linked values of political equality and control, we can therefore still properly label practices as having 'democratic' qualities even where they contribute to one of these dimensions more than the other. This approach enables us to assess the democratic qualities of a range of non-ideal scenarios in which democratic imperfections sometimes emanate from weaknesses of political control mechanisms, and sometimes from difficulties in realising substantive political inequality.

By freeing itself from institutionally-specific assumptions, the concept and language of democratic practices reminds us that the legitimacy conferred by democratic institutions is ultimately derived from their capacity to promote purposes and perform functions informed by these democratic principles, rather than from any intrinsic value embodied in particular, historically contingent, institutional mechanisms. Such an approach thus distinguishes between normative assumptions about how the foundational values of democracy are to be understood, and strategic considerations regarding what institutions need to look like if they are to realize underlying democratic values.

By separating itself from idealised assumptions about the transformative power of democratic institutions, the notion of democratic practices helps us maintain our focus on evaluating how much work given institutions do in promoting democratic values, rather than assessing whether democratic values have been 'fully' (or almost fully) realised. Working with the concept of 'democratic practices' thereby helps us to perform our task of analysing and appraising progressive processes of democratization, where these unambiguously fall short of realizing a more comprehensive notion of fully formed 'democracy'. Rather than attempting to answer a speculative question about the potential attainment of fully fledged 'global democracy', it helps us to focus on meaningful forms of democratic change that can be achieved in the present.

This way of thinking about democratic practice is not only more accurate in assessing processes of democratisation, ${ }^{16}$ it is also more useful as a basis both for grounding social critique and guiding social transformation. This approach recognises that democratic

\footnotetext{
${ }^{14}$ T. Macdonald, Global Stakeholder Democracy: Power and Representation Beyond Liberal States (Oxford: Oxford University Press, 2008); M. Goodhart, 'Human Rights and Global Democracy', Ethics and International Affairs, 22 (2008), p.401.

${ }^{15}$ Clearly, given our desire to avoid building institutionally specific assumptions into our democratic concepts, these principles of political control and political equality cannot themselves be understood in institutionally specific ways. We understand these principles in a broadly conventional way to require that indivdiuals within a given democratic polity have equal influence over the systems of public decisions that affect them. However, we make no assumptions about the institutional character of relevant public decision making systems, or the instituional modalities through which such equal influence is exercised.

${ }^{16}$ R. Goodin, 'Global Democracy: In the Beginning', International Theory, 2 (2010), pp. 175-209.
} 
principles can be advanced through practices that do not necessarily have democracy as an explicit or primary objective. ${ }^{17}$ It also acknowledges the value of democratic practices that advance greater equality or political control, but not necessarily both simultaneously. This requires that we think in a fundamentally different way about the prospects for global democratization than approaches that have dominated the literature to date.

\section{Misconceptions about 'global democracy'}

Although we are careful in our own analysis to assess the democratic quality of emerging systems of global governance in ways that are not wedded to institutionally specific or overly idealised assumptions about what global democratic institutions might look like, such assumptions are often hardwired into mainstream discourses surrounding the prospects of global democratization. In this section, we explore in greater depth how such misplaced assumptions lead global democratic sceptics astray.

\section{Democratic institutions imagined through a statist lens}

We begin by examining how analogies between democratic institutions at national and global levels are often cast in inappropriately institutionally specific terms, which conceptualise too narrowly what forms global democratic institutions and practices could take. This misleads us in important ways about what democratic models at the global level might look like, and the scope for uncharted forms of institutional innovation. In other words, these assumptions lead global democratic sceptics to unduly pessimistic conclusions because they fail to recognise the potential of non-state institutions to perform useful democratic functions via alternative means.

One common way of conceptualising democracy views particular institutional mechanisms familiar from national democratic contexts - such as elections, accountability mechanisms, deliberative processes and so on - as simply constitutive of democracy. Institutionally specific assumptions of this kind sometimes operate as what we might think of as conceptual default options, hardwired into analytical frameworks without much critical reflection or explicit justification. The problem with such deeply embedded assumptions is that although we might observe that institutional strategies common at the national level seem often or even usually to be required as means of promoting democratic values and purposes, the proposition that these practices comprise a necessary basis for democratic values to be meaningfully promoted cannot be simply assumed.

\footnotetext{
${ }^{17}$ We therefore recognise that the social practices we are describing as democratic are not exclusively or distinctively democratic, and could plausibly be otherwise interpreted, for example as instances of transnational accountability R. O. Keohane and J. S. Nye, 'Democracy, Accountability and Global Governance', in D. Held and M. Koenig-Archibugi (eds.) Global Governance and Public Accountability (New Jersey: Wiley-Blackwell, 2004)., as global administrative law B. Kingsbury, 'Global Governance as Administration - National and Transnational Approaches to Global Administrative Law', Law and Contemporary Problems, 68 (2005), or as institutions protective of rights T. Macdonald, 'The Liberal Battlefields of Global Business Regulation', Ethics and Global Politics, 3 (2010), pp. 303-24.. Indeed, these distinct practices often develop through deeply interconnected processes, as they have done within more fully blown 'democracies' at the national level. Moreover, they are often grounded in common values, and can support each other functionally in important respects M. Goodhart, Democracy as Human Rights: Freedom and Equality in the Age of Globalization (Routledge, 2005), T. Christiano, 'An Instrumental Argument for a Human Right to Democracy', Philosophy \& Public Affairs, 39 (2011), pp. 142-76..
} 
Especially in light of the significant differences in potentially relevant social and institutional conditions between the national and global levels, a more systematic consideration of which kinds and combinations of institutions are likely to be most effective in promoting democratic values under varying conditions seems to be required. For example, notions of democracy that conceptualise institutionally specific practices such as elections as being constitutive of democracy (such as Dahl), ${ }^{18}$ fail to take seriously the possible non-electoral institutional forms that decentralised and multi-level global democratic practices might take. ${ }^{19}$ In this way, narrow assumptions about necessary institutional forms can constrain both interpretations of and efforts to promote democratic institutional innovation.

Another assumption that pervades existing definitions and representations in the literature is a view of democracy as needing to function through 'state-like' institutions, in the sense of specialised political institutions with a highly centralised structure. ${ }^{20}$ This assumption is often justified with reference to claims that there is something special about the capacities of statelike institutions that are necessary for democracy to function. For example, Christiano rehearses the range of functions and powers of modern states, and concludes that "the state is the only instrument available for [performing these functions]". ${ }^{21}$

We don't dispute the claim that states possess distinctive functional qualities. However we do suggest that claims about the lack of functional substitutes for these particular institutional forms are seriously overstated. Empirical research within private governance and regulatory literatures suggest that, despite their undeniable value, these specific capacities are neither sufficient nor necessary conditions for the exercise of effective power. ${ }^{22}$ Moreover, extensive empirical literatures on global regulatory and governance deficits illustrate the significant weaknesses of effective state power at the national level under conditions of globalisation. ${ }^{23}$ In this sense, the ideal-type image of the bounded, centralized state, capable of subordinating other forms of social power in the exercise of its own democratic mandates - is rarely given concrete institutional embodiment within actually existing states.

Despite such evidence, the view that centralised, state-like institutions are required before it is worth investing in the promotion of global democratization remains pervasive. Nagel, for example, has forcefully put the view that democratic practices cannot be created unless there is already a sovereign institutional structure of some kind for democratic norms to 'go to work on'. ${ }^{24}$ Likewise, Buchanan and Keohane highlight the absence of a "global political structure that could provide the basis for democratic control", as a foundation for claiming that global democracy under present or reasonably foreseeable conditions is not feasible. ${ }^{25}$

\footnotetext{
${ }^{18}$ R. A. Dahl, Democracy and its critics.

${ }^{19}$ T. Macdonald and K. Macdonald, 'Non-Electoral Accountability in Global Politics: Strengthening Democratic Control within the Global Garment Industry', European Journal of International Law, 12 (2006), pp. 89-119.

${ }^{20}$ Sometimes this is implicit, as in relation to Dahl's critiques of trade-offs between citizen participation and the scale of government (R. A. Dahl, Democracy and its critics). At other times this is explicit, as in the case of $\mathrm{M}$. Koenig-Archibugi, 'Is Global democracy Possible?.

${ }^{21}$ T. Christiano, 'A Democratic Theory of Territory and Some Puzzles about Global Democracy', Journal of Social Philosophy, 37 (2006), pp. 81-107., p.12

${ }^{22}$ L. Snider, 'Accommodating Power: the `Common Sense' of Regulators', Social Legal Studies, 18 (2009), pp. 179-97, M. Koenig-Archibugi, 'Is Global democracy Possible? ', European Journal of International Relations, 7 (2010), pp. 519-42, p.9

${ }^{23}$ See for example D. Held and M. Koenig-Archibugi, Taming globalization : frontiers of governance (Cambridge, UK: Polity Press, 2003).

${ }^{24}$ T. Nagel, 'The Problem of Global Justice', Philosophy and Public Affairs, 33 (2005).

25 A. Buchanan, \& Robert O. Keohane, 'The Legitimacy of Global Governance Institutions', p.416. See also R. Goodin, 'Global Democracy: In the Beginning', International Theory, 2 (2010), pp. 175-209., p.200.
} 
One important empirical fact that such arguments neglect is that - while centralised and allencompassing institutions certainly have functional properties that decentralised institutions lack - the latter can still exercise effective (albeit importantly limited) power, of kinds that can be meaningfully democratised. As Goodin observes, looking upon the piecemeal array of functionally-specific and decentralised governance institutions existing at the global level, "whoever said - whoever would think - that only central authorities with a perfectly general remit admit of being democratized? ... Would democratizing the partial and piecemeal institutions of global governance amount to a contribution toward global democracy? Surely it would." 26

Whatever we might conclude about the degree of functional superiority possessed by statelike institutional forms, it doesn't follow that decentralised structures of effective power are therefore inappropriate subjects for democratisation. If we believe in the values of democracy as something important to pursue, then the democratic project can't be dismissed simply because the democratic institutions that are accessible at any given time (given prevailing social technologies and conditions) are highly non-ideal, vis a vis imagined or experienced alternatives that are inaccessible under prevailing conditions.

\section{Statist democratic practices conceptualised in overly idealised terms}

If we are going to learn lessons from national democratic experiences to inform debates about the feasibility of global democracy, we also need to be more realistic about what 'democracy' at the national level actually entails. Critics of global democratic models often attempt to score cheap points by dismissing proposals for global democratic reform as grounded in a naive idealism that fails to grasp the limitations of real world politics. However, such critics share with some advocates of global democracy idealised notions of what democracy can be expected to achieve in even the most conducive real world social conditions.

The embrace by global democratic sceptics of idealized views of national democratic institutions mean that the bar is set much too high in existing accounts of what a global democratic system would need to look like to protect the idealised values and purposes of democracy in meaningful ways. This misleads us about the potential contribution of gradualist projects of global institution building to broader democratic ambitions, wrongly disparaging the value of supporting incremental transformative projects.

The typical image of feasible democratic expectations is usually constructed with implicit or explicit reference to what List and Koenig-Archibugi refer to as "well functioning states or other state like entities, say those of established democratic countries". ${ }^{27}$ Certainly, most authors acknowledge that existing national democracies are imperfect in many ways, but this concession tends not to be taken sufficiently seriously in the way analogies and arguments continue to be constructed. Despite acknowledgement of weaknesses and imperfections, it is nevertheless assumed that we can talk straightforwardly about a "reasonable threshold of democracy", ${ }^{28}$ which at least roughly approximates the ideal. Such qualifications are thereby quickly put to one side, as analytical frameworks continue to be built on the foundations of an idealised statist ontology.

\footnotetext{
${ }^{26}$ R. Goodin, 'Global Democracy: In the Beginning', p.201

${ }^{27}$ C. List and M. Koenig-Archibugi, 'Can There Be a Global Demos? An Agency-Based Approach ', p.92

${ }^{28}$ C. List and M. Koenig-Archibugi, 'Can There Be a Global Demos? An Agency-Based Approach '.
} 
For example, Christiano repeatedly acknowledges the 'imperfections' of national democracies, ${ }^{29}$ yet still develops an argument based on quite elaborate assumptions about their functionality, saying for instance that 'modern political societies' "are characterized by comprehensive systems of provision and regulation of the basic needs of all the citizens. ... They provide comprehensive systems of law enforcement. They create highly unified and integrated internal markets that are regulated in unified and systematic ways. .... All of these activities and more, which implicate the fundamental interests of their citizens, are done in a highly unified way that looks to the overall interests of all citizens and attends to the basic fairness of the system as a whole". Certainly these are important aspirational goals of modern democratic states, but in most cases states fall far short from actually realising these aspirations in anything but a shallow and formal sense.

This tendency to conduct discussion mainly with reference to an idealised image of 'well functioning' democracies brushes over the fact that in most actually existing democracies, deep disagreement, conflict and inequality is pervasive, and can be accommodated only in limited ways by democratic institutions. For this reason, examples that are so often placed to one side as exceptional 'hard cases', such as divided societies, ${ }^{30}$ are better understood as the 'thick end of the wedge', in the sense that the tensions and barriers that these societies so visibly struggle to manage are in fact present in significant ways in all national democracies. For example, problems such as social exclusion, cumulative forms of social and political inequality, denial of rights to indigenous communities and some categories of migrants, and so on, can be found to varying extents across all actually existing democratic societies. Moreover, many democratic systems are now feeling the strain of societal pluralisation, reflected in low electoral participation rates, dissatisfaction with party politics and a so-called 'democratic deficit'. ${ }^{31}$ Well- functioning democracy is simply a highly idealistic and very difficult thing to achieve under any real world social conditions, and this point is often not taken sufficiently seriously. ${ }^{32}$

Furthermore, much existing analysis fails to take seriously the gradualism with which democratic institution building so often proceeds. As Goodin argues at some length, democracies at the national level developed progressively over time, and the same may well be true of global democratic institutions. ${ }^{33}$ Certainly, it is common for gradualism to be acknowledged in some form, and corresponding distinctions between 'weaker' or 'stronger' versions of global democracy to be recognised. ${ }^{34}$ Nevertheless, the pervasive assumption that meaningful promotion of democratic principles at the global level would require "dramatically reconstructed social relations" in the foreseeable term persists. ${ }^{35}$

\footnotetext{
${ }^{29}$ T. Christiano, 'A Democratic Theory of Territory and Some Puzzles about Global Democracy'. For example, on p.94 he says that the achievements of liberal democratic societies are "highly imperfect and only partly living up to the ideals of democracy”.

${ }^{30}$ See, for example, C. List and M. Koenig-Archibugi, 'Can There Be a Global Demos? An Agency-Based Approach ', pp.87-88

${ }^{31}$ M. Crozier and A. Little, 'Democratic Voice: Popular Sovereignty in Conditions of Pluralisation ', Australian Journal of Political Science, 47 (2012), pp. 333-46.

${ }^{32}$ R. Geuss, Philosophy and Real Politics (Princeton: Princeton University Press, 2008).

${ }^{33}$ R. Goodin, 'Global Democracy: In the Beginning'.

${ }^{34}$ For example, M. Koenig-Archibugi, 'Is Global democracy Possible? ', quotes Michael Doyle saying that "no strong version of global democracy is viable at the present time”. Similarly, D. Miller, 'Against Global Democracy', in K. Breen and S. O'Neill (eds.) After the Nation: Critical Reflections on Post-Nationalism (Basingstoke: Palgrave Macmillan, 2010) discusses some dimensions on which democracy might be weaker or stronger, depending on the extent of political control, political equality and the scope of issues brought into democratic decision making in a given case.

${ }^{35}$ Schweller cited in M. Koenig-Archibugi, 'Is Global democracy Possible? '.
} 


\section{Social conditions underpinning democratic practices}

Debates about the feasibility of global democracy not only misconceptualise important features of what democratic practices ought to look like, they also misconceptualise the social conditions necessary to underpin democratic institutions and practices.

Existing discussions about the feasibility of global democracy have done much useful work in identifying relevant social conditions that underpin democratic institutions at the national level. ${ }^{36}$ Individual authors focus their analysis on social conditions of very different kinds, with some concentrating on the characteristics of political actors and institutions, and others looking at underlying social and cultural dynamics. Some authors focus on analysis of the characteristics of and relationships among individuals within a democratic society ('the demos'). ${ }^{37}$ Others focus on the wider social systems and institutions in which the demos is constituted, and thereby through which relations of social power, social identities, shared systems of meaning and value, and structural interests associated with these, are generated and given meaning. ${ }^{38}$ Although the focus of these different analyses varies widely, it is possible to draw out three broad categories of social conditions that recur frequently within such discussions.

The first is shared values, beliefs or identities, which are widely regarded as playing a central role in binding together a particular social grouping of individuals. The relevance of this category of social conditions is elaborated in different ways. Some authors focus on "sympathetic identification" as important for motivational reasons, by giving members of the group reasons to accommodate the values and interests of others. ${ }^{39}$ Common beliefs and values are also argued to matter since a democracy whose authority is acceptable to all requires that the majority should not attempt to impose "a wholly alien world-view on the minority". ${ }^{40}$ This motivational argument is also explicit in Rawls: "only an intense process of socialization and awareness of participating in a common enterprise, such as those characterizing fellow citizens, can motivate persons' continued support to a permanent scheme of economic redistribution". ${ }^{41}$ Such shared values, beliefs and cultures are also seen to be important because of their role in facilitating mutual intelligibility within processes of public deliberation. ${ }^{42}$ Moreover, interpersonal trust is regarded as providing an important basis for sustaining the kinds of reciprocity required for people to play by the rules of the democratic game even when this goes against their values or interests in particular circumstances. $^{43}$

\footnotetext{
${ }^{36}$ Similar analysis has been developed in the literature on global justice, where scholars have sought to identify the kinds of background social conditions on which obligations of justice depend (eg. C. Barry and L. Valentini, 'Egalitarian challenges to global egalitarianism: A critique', Review of International Studies 35 (2009), pp. 485512, R. Pevnick, 'Political Coercion and the Scope of Distributive Justice', Political Studies, 56 (2008), pp. 399413..

${ }^{37}$ C. List and M. Koenig-Archibugi, 'Can There Be a Global Demos? An Agency-Based Approach '.

${ }^{38}$ Miller, 'Democracy’s Domain'

${ }^{39}$ D. Miller, 'Democracy’s Domain'

${ }^{40}$ D. Miller, 'Democracy's Domain'

${ }^{41}$ Cited in C. Barry and L. Valentini, 'Egalitarian challenges to global egalitarianism: A critique', Review of International Studies 35 (2009), p.508.

42 D. Miller, 'Democracy’s Domain', M. Koenig-Archibugi, 'Is Global democracy Possible? '.

${ }^{43}$ D. Miller, 'Democracy’s Domain'.
} 
The second widely analysed category of relevant social conditions relates to the importance of shared interests as a basis for motivating the acceptance of democratic authority. As Miller suggests, "For democracy to be possible, there must be the possibility of some compromise solution where each gain to some extent, even in spite of fierce disagreement about the nature of the compromise." ${ }^{44}$

Third, many commentators view reasonably plural distributions of social power or resources as an important social requisite for democracy. Perhaps the most fundamental reason for this is the role of power distributions in enabling democratic stakeholders to demand responsiveness from political decision makers (or preventing them from doing so). Vanhanen for example claims that "democratisation takes place under conditions in which power resources have become so widely distributed that no group is any longer able to suppress its competitors or to maintain its hegemony". ${ }^{45}$ In this way, underlying distributions of social and economic power have important motivational implications for political decision makers, giving reasons for them to accept democratic authority.

Although identification of these broad categories of relevant social conditions is a useful starting point for understanding potential pathways and obstacles to global democratic reform, such analysis of social conditions has often been extrapolated to the global context in ways that are similarly problematic to analysis of democratic institutions, discussed above. First, existing discussions tend to portray prevailing social conditions at the national level in overly idealised terms, characterising levels of trust, solidaristic sentiments and so on in much rosier terms than seems supported by evidence about how actually existing democratic societies function. In particular, there is a tendency to downplay the pervasive forms of social inequality and difference - in some cases intractable or incommensurable - that characterise all actually existing democracies at least to some extent.

Much discussion also seems to assume that roughly the same configurations of relevant social conditions that have supported democratic institutions within many national democracies would need to be replicated within any social context capable of sustaining meaningful democratic practices. For example, Christiano's account of the requisite character of shared interests is based on a very specific conceptualization of how mutual gains from submission to democratic authority are achieved within a nation state. ${ }^{46}$ This account characterizes members of national societies as inhabiting a 'common world', entailing "a set of circumstances among a group of persons in which ... the fulfilment of all or nearly all of the fundamental interests of each person are connected with the fulfilment of all or nearly all of the fundamental interests of every other person." 47 The existence of this kind of common world is seen as an important foundation for democratic practice because of the opportunities it generates for implicit or explicit cross-payments across different issues. However, while Christiano presents a strong theoretical case that this configuration of interests plays an important role in motivating democratic practices within many existing nation states, it doesn't follow that this is the only way in which such motivation could be established.

\footnotetext{
${ }^{44}$ D. Miller, 'Against Global Democracy', in K. Breen and S. O'Neill (eds.) After the Nation: Critical Reflections on Post-Nationalism (Basingstoke: Palgrave Macmillan, 2010).

${ }^{45}$ Cited in M. Koenig-Archibugi, 'Is Global democracy Possible? '

${ }^{46}$ T. Christiano, 'A Democratic Theory of Territory and Some Puzzles about Global Democracy'.

${ }^{47}$ The common world is distinguished from 'partial associations' (p.86) in which there is no reason to think that the interests of the members are equally at stake in that association.
} 
Such motivation could be grounded in interest-based configurations of alternative kinds, resulting less from extant 'structural' conditions of deep interdependence, and more from the strategic imposition of sanctions on those resisting democratic norms. Although offering a weaker motivational basis for compliance with democratic authority than deep structural sources of overlapping interest, such strategically manufactured shared interests can be complemented by interactions with conducive social conditions of other kinds to bolster the requisite motivational foundations.

This observation illustrates a broader point, which is that it is actually extremely difficult to 'read off' from examination of a relevant set of social conditions what the prospects are for democracy to emerge. ${ }^{48}$ The one overarching condition that really matters is the motivation of the powerful to accept democratic authority. And such motivation can be constructed on different foundations under different circumstances.

The implications of prevailing social conditions for the possibility of establishing meaningful global democratic practices therefore depends not only on the 'magnitude' of barriers presented by a given set of social conditions, but also on how structural conditions interact in any particular context. Such interactions are often importantly determined by the ways in which these 'structural', background conditions are mobilised and resisted by political agents. The scope for working creatively around prevailing barriers is further enhanced by the diversity of institutional strategies available to at least the more innovative of democratic agents. As we shall see below, because different democratic institutions depend on social conditions of different kinds, it is sometimes possible for these transformative agents to work creatively to build appropriate kinds of democratic institutions around the obstacles that are encountered in a given context. Even under highly inhospitable social conditions, there are therefore various pathways available through which flawed yet meaningful democratic practices can potentially be built around prevailing social obstacles in a given context.

In other words, we suggest that the fixation of global democratic sceptics on an idealised and state-centric view of what democratic institutions require encourages them to reach excessively structuralist conclusions, in which unconducive structural conditions within the global social order are seen to present insurmountable obstacles to global democratic progress. Conversely, such accounts underplay the potential for innovative transformative agents to build effective strategies of democratic institution-building around the obstacles they confront.

\section{The inter-dependence of social conditions and political institutions}

To illustrate this central argument, we examine two contrasting case studies - one analysing democratic practices at the national level, and one focused on the global level. The nationally focused case study examines the pursuit of democratic practices in Northern Ireland. Most commentators would recognise this as a case where 'democracy' in a fully-fledged sense has been attained, though the pursuit of democratic practices has faced significant obstacles, and major weaknesses in democratic practices remain. The 'global' case examines the gradual democratisation of global business regulation. Most observers - ourselves included - would not regard these democratic practices as meriting the label 'global democracy'; our point is

\footnotetext{
${ }^{48}$ M. Koenig-Archibugi, 'Is Global democracy Possible? ' comes to a similar conclusion.
} 
rather to highlight the processes through which meaningful (albeit still highly imperfect) democratic practices have nonetheless been established. ${ }^{49}$

Our selection of these two cases reflects the goal of comparing "uncommon cases", to assist our understanding of how "similar mechanisms of change combine differently with varying environmental conditions" in driving trajectories of social change in "substantially divergent" social contexts. ${ }^{50}$ Each case study was analysed separately, using what is sometimes called a 'within-case' method of qualitative analysis - a model that aims to directly analyse evidence on causal mechanisms or processes and other intervening variables that feed into explaining observed events and outcomes. ${ }^{51}$ Within each case, we analyse prevailing social conditions, obstacles encountered and the strategies of political agents who try to work around social obstacles in creative ways. To the extent that we are comparing the two cases, the goal is not to isolate the causal significance of particular 'variables' that we can control across the cases, but rather to compare complex and path dependent causal processes in a holistic manner across the two separate cases.

By drawing out the common underlying dynamics through which processes of democratic change are advanced and obstructed in these two divergent cases, we challenge those global democratic sceptics who assume a polarized contrast between relatively conducive conditions facing national democracies, and insurmountably unconducive conditions at the global level. In contrast, analysis across the two cases illustrates the deep contingency of how 'structural' obstacles play out in any given context, and the significant space for transformative agency to work around prevailing obstacles at global as well as national levels.

This is not to suggest that there are no situations in which democratization of a meaningful kind will prove infeasible. Neither is it to suggest that background social conditions do not influence processes of institutional transformation. In contrast, our cases both show these conditions to importantly influence the particular types of democratic practices that can feasibly be established and sustained. We are therefore certainly not suggesting that global democratic practices are likely to resemble national practices in institutional terms, or that they are comparable in their current capacity to protect democratic values. Our point is simply that democratic change at both national and global levels can be feasible under a diverse range of highly inhospitable conditions.

\section{Democracy in Northern Ireland: The 'Thick End of the Wedge'}

Political developments in Northern Ireland in the last twenty years provide an instructive counterpoint to some of the assumptions that have underpinned arguments about global democracy in recent years. In the 1990s Northern Ireland moved from a society blighted by violent conflict through a process of peace-building and containment to the development of a new set of democratic institutions following the 1998 Belfast Agreement. Although there was a history of democratic government, it was seriously flawed and several new institutional

\footnotetext{
${ }^{49}$ In making this point, these cases serve a purely illustrative purpose, and we could have chosen other cases with these same characteristics to make our point. However we certainly don't claim that these cases are 'representative' of any broader set of relevantly similar cases; indeed, recognition of the idiosyncratic nature of individual cases is central to our argument.

${ }^{50}$ D. McAdam, S. Tarrow and C. Tilly, Dynamics of Contention (Cambridge: Cambridge University Press, 2001), pp.82-83

${ }^{51}$ A. Bennett and A. George, L, 'Research Design Tasks in Case Study Methods', Paper presented at MacArthur Foundation Workshop on Case Study Methods, Harvard, October 17-19, (1997).
} 
mechanisms needed to be established through the peace process to make the new system workable. Compared with nascent forms of global democracy, democratic institutionbuilding in Northern Ireland had the advantage of operating within specified territorial boundaries. However, the institutions that were established through the Belfast Agreement still had to work around the highly contested nature of these boundaries. There were (and continue to be) pervasive obstacles to democratic processes but also a number of enabling conditions which facilitated these political developments. A number of political strategies had to be developed to get around prevailing social barriers, and a range of innovative democratic practices had to be constructed to enable political progress.

The example of Northern Ireland demonstrates the ways in which democratic processes can be developed in inhospitable conditions, including those of serious social division and conflict. In this sense, Northern Ireland can be understood as the 'thick end of the wedge' bringing into view many of the obstacles and processes that exist within all national democratic contexts, but which are not always readily visible. Thus, rather than analysts of global democracy focusing on idealised versions of nation-state democracy from which difficult cases are excluded, it is more useful to engage with these difficult cases so that we can learn lessons about the nature of social obstacles that debates about global democracy must confront.

\section{Adapting to prevailing social obstacles}

The social and political obstacles to democracy in Northern Ireland are manifold and have challenged democratic practices before and after 1998. Northern Ireland has always been highly divided and not just on sectarian or ethno-national lines. The most deprived communities not only endured the worst of the violence during 'the Troubles' but have enjoyed the benefits of 'peace' to a much lesser extent than more privileged societal sectors. Thus, for example, while there has always been an element of a shared experience between working class communities in Northern Ireland, the ethno-national divide has made it extremely difficult to articulate that joint experience, let alone mobilise it politically.

Similarly, the elite driven political structure of Northern Ireland rendered groups such as women and ethnic minorities virtually invisible, with a concomitant narrowing of the political agenda that neglected their particular interests. ${ }^{52}$ In terms of developing democratic processes then, the conflict in Northern Ireland generated a number of constraints - such as complex cross-cutting differences across the ethno-national divide - that provided an inhospitable social backdrop. If so many obstacles existed and remain prominent now, how could the developments of the 1990s take place and why have they endured?

Despite the less than ideal socio-political circumstances, Northern Ireland managed to develop a new set of democratic institutions following the Agreement and these processes have largely survived the continuing low-level conflict in the intervening years. Undoubtedly, social conditions in Northern Ireland in the 1990s were more conducive to democratic change than had previously been the case, as people had become increasingly war weary. ${ }^{53}$ Moreover

\footnotetext{
${ }^{52}$ A. Little, 'Feminism and the Politics of Difference in Northern Ireland', British Journal of Politics and International Relations, 7 (2002), pp. 163-77, A. Little, Democracy and Northern Ireland: Beyond the Liberal Paradigm? (London: Palgrave, 2004).

${ }^{53}$ Although we focus here on the opportunities that emerged from the domestic context, it is undoubtedly true that the broader international context also made an important contribution. For discussion of the contribution of the Clinton administration see T. J. Lynch, Turf War: The Clinton Administration and Northern Ireland
} 
there was a political stalemate in which most republicans and the British government had come to recognise that this was a war that could not be won. Thus, the impetus for political change was less focused on the possibility or desirability of democracy at that moment, and more concerned with the potential ending of paramilitary violence and the opportunities that might emerge for greater democratic engagement thereafter.

Importantly however, there was a political dimension to the peace process that went beyond the pragmatism engendered by war weariness and the socio-economic benefits of the peace dividend. During the negotiations it became clear that a form of accommodation might be possible where all political objectives would be viewed as legitimate including, most significantly, the aspiration to eventually replace the local democratic structures as part of a reunited Ireland. This increased legitimacy of alternative visions of the future was a form of recognition whereby the inability of either side to merely wield majority power led to a degree of mutual understanding that democratic authority had to be based within shared institutions. Although numerous social, cultural and political barriers remained, by the 1990s the peace process had inched towards a situation in which some form of democratic arrangement based on power sharing had sufficient traction to move towards transition.

Perhaps most significantly of all, a situation emerged in which actors on the fringes of formal political processes (e.g. representatives of paramilitary organisations) were finally - though only gradually and partially - legitimised as bona fide democratic actors following the ceasefires. The 'back channel' communications that had existed between the British government and the IRA for many years became more explicit, thereby legitimising republicanism as a political perspective and validating its representatives as rightful members of democratic processes. ${ }^{54}$ Ultimately, the pathway to political transition was always going to involve engagement with perpetrators of violence on both sides of the ethno-national divide. This would thereby provide potentially democratic voice to groups which had only been on the fringes of mainstream political debate.

Although there were significant social and political obstacles to the peace dividend in Northern Ireland, the process outlined above involved a concomitant effort on the part of the participants in the peace process to develop both political structures that could form a new set of democratic institutions, as well as a strategy to inculcate a commitment to transformative processes from the main political actors. In this light, the process of democratic change in Northern Ireland had to couple the encouragement of new forms of transformative agency with institutional innovation.

\section{Transformative agency and institutional change}

It is clear that a majoritarian model of representative democracy could not be parachuted into the context of Northern Ireland. What it required instead was a concurrent process of

(Aldershot: Ashgate, 2004). For analysis of the European Union input to the peace process, see S. Byrne and C. Irvin, 'Economic aid and policy making: building the peace dividend in Northern Ireland', Policy \& Politics 29 (2001), pp. 413-29, L. O’Dowd and C. McCall, 'Escaping the Cage of Ethno-National Conflict in Northern Ireland? The Importance of Transnational Networks', Ethnopolitics, 7 (2008), pp. 81-99, L. Racioppo and K. S. See, 'Grassroots Peace-building and Third-party Intervention: The European Union's Special Support Programme for Peace and Reconciliation in Northern Ireland', Peace \& Change, 32 (2007), pp. 361-90, A. Williamson, D. Scott and P. Halfpenny, 'Rebuilding civil society in Northern Ireland: the community and voluntary sector's contribution to the European Union's Peace and Reconciliation District Partnership Programme', Policy \& Politics 28 (2000), pp. 49-66.

54 J. Powell, Great Hatred, Little Room: Making Peace in Northern Ireland (London: The Bodley Head, 2008). 
discussion about the kinds of political mechanisms that would be required to build democratic processes, which would then enable a reconstituted demos to function. In this sense, the social conditions did not precede the political institutions or vice versa; rather, both developed simultaneously through a complex choreographical process. ${ }^{55}$ Thus the changes that took place were not entirely beholden to structural context, but depended on the capacity of transformative agents to take advantage of the contextual conditions to forge new transitional democratic practices. In terms of the development of institutional processes for democracy, a new and innovative political architecture was required that both reflected existing social conditions and was responsive to their changing nature.

The process of manoeuvring around social and cultural barriers in Northern Ireland was substantial and arduous, and required a series of political strategies to develop new democratic practices. The model that emerged did not fall into place as a result of a particular set of conditions but was the outcome of sustained political engagement and negotiation on numerous levels. While the local, national and international political environment was more conducive in the 1990s than it had been for many years, the key point is that all of these conditions overlapped in complicated ways such that it was not just a matter of taking advantage of conducive conditions. Those very conditions were constructed through nascent forms of democratic engagement rather than emerging fully-fledged as a platform from which democracy could be established.

The consociational model established in Northern Ireland is not without criticism, ${ }^{56}$ but it reflects the ways in which democratic processes need to be tailored for the specific contexts in which they are being implemented. In Northern Ireland this involved elements such as an executive comprised of a grand coalition of the major parties, and cross-community support for legislation (that is, effectively, both a majority and minority veto). This required a process of designation whereby Assembly members had to nominate themselves as Unionist, Nationalist or Other to ensure that cross-community support in the Assembly could actually be measured. These aspects of the model were specifically designed to institutionalise power sharing amongst a number of political parties and to prevent majorities from using their power to subjugate minorities.

Like all consociational systems, it is an elite driven political model that is designed on the basis that accommodation between political elites will filter down to change social conditions by encouraging less community antagonism in the future. So the system that was established reflected the very divisions that it was designed to transcend, as reflected in the process of designation. The intention was that over time the process of governing together at elite level would engender greater awareness of shared interests across the ethno-national divide and eventually the diffusion of a more reconciliatory ethos through society.

Simultaneously, the Agreement turned on a number of specific controversial measures that were directly related to the structural conditions of the conflict. Thus, the Agreement makes specific recommendations around the regulation of parades and marches, the use of language

\footnotetext{
${ }^{55}$ P. Dixon, 'Political skills or lying and manipulation? the choreography of the Northern Ireland peace process', Political Studies, 50 (2002), pp. 725-41, P. Dixon, The Northern Ireland Peace Process: Choreography and Theatrical Politics (London: Routledge, 2010).

${ }^{56}$ A. Little, Democracy and Northern Ireland: Beyond the Liberal Paradigm? (London: Palgrave, 2004).; Wider debates on the establishment and nature of consociationalism in Northern Ireland are examined in R. Taylor, Consociational Theory (London: Routledge, 2009), R. Wilford, Aspects of the Belfast Agreement (Oxford: Oxford University Press, 2010)..
} 
and other symbolic cultural practices, the reform of the police service and the justice system, the decommissioning of paramilitary weapons, and a release scheme for paramilitary prisoners. The key here is that the development of democratic institutional processes alone was never going to be enough to facilitate political development in Northern Ireland. Indeed, the possibility of developing those processes was largely dependent on a range of other social, cultural and political initiatives to facilitate transformative agency that had to be developed in tandem with institutional structures.

The peace process also involved concerted efforts to find forms of involvement for groups such as women who had traditionally been marginalised in the Northern Irish polity. For example, new parties such as the Northern Ireland Women's Coalition were encouraged and new institutional bodies such as the Civic Forum were established to complement the Assembly which, by design, would be dominated by political elites. ${ }^{57}$ The creation of the Civic Forum was developed to offset the reinforcement of elite-driven, ethno-national politics in the Assembly and the consociational structure of its executive and legislative institutions. The Civic Forum would enable greater grassroots participation from more diffuse sections of society. Thus, not only would it potentially be less bound by the politics of the ethno-national division but it also would provide opportunities for voice and participation from a wider range of social interests and identities than had hitherto been the case.

The example of Northern Ireland shows that democratic practices can evolve in inhospitable circumstances if developed in ways that are contextually sensitive, not bound by a range of rigid pre-conditions and facilitative of transformative agency. The developments in Northern Ireland involved more than a new political architecture; they also reflected the ways in which political institutions are grounded in power-laden social contexts. In the case of encouraging new political actors, we can see that there were attempts to reconstitute the Northern Irish demos but at the same time, and somewhat paradoxically, political progress required a shoring up of the very political elites that had hitherto been obstacles to change. Similarly, while undoubtedly motivated by a transformative ethos, democratic change in Northern Ireland could not take place without reference to and reinforcement of the ethno-national divide which was at the heart of the political problem. Beyond a desire for an end to political violence, there was little by way of shared values that underpinned the democratising of Northern Ireland - indeed, in many ways the institutions shored up the notion of a divided society.

Many of the structural problems which acted as obstacles to democratic progress in Northern Ireland still feature prominently in everyday life. The ethno-national conflict was not resolved by the Agreement, but rather a set of democratic processes were established to enable the management and transition of continued ethno-national tensions and sectarian violence. It is clear that Northern Ireland is not a reconciled society and that overt symbolic expressions of conflict remain a resilient feature of everyday life in the province. ${ }^{58}$

Therefore, democratic transition should not be imagined as a way of replacing conflict with political institutions, but as a non-ideal way of managing and transforming those conflicts through greater democratic engagement. The institutionalisation of democratic mechanisms has not overcome the obstacles and structured social conditions referred to above, but it has contributed to their management and transition. This suggests that theorists and practitioners

\footnotetext{
${ }^{57}$ A. Little, Democracy and Northern Ireland: Beyond the Liberal Paradigm? (London: Palgrave, 2004).

${ }^{58}$ A. Little, 'Disjunctured Narratives: Rethinking Reconciliation and Conflict Transformation', International Political Science Review, (2012 ).
} 
interested in the creation of new democratic practices at the global level need to pay more attention to processes through which political institutions and social conditions can be gradually transformed in accordance with democratic principles, rather than fixating on the 'achievement' of democracy in a fixed or settled fashion.

\section{Democratising global business regulation: a case of democratic gradualism}

To explore dynamics of democratization at the global level, we now turn our attention to emergent (albeit still rather embryonic) efforts to promote democratic values within the transnational institutional relationships linking powerful businesses to marginalised workers and producers in other parts of the world. In this case, as in that of Northern Ireland, meaningful processes of democratization have been advanced under highly inhospitable social conditions. Such change has been enabled importantly by the development of democratic institutions able to work creatively within and around the distinctive social obstacles encountered. The capacity of these institutions to promote democratic values remains limited in serious ways, and the democratic practices described below remain a long way from complying with any idealised notion of what democracy requires. Nevertheless, such processes of democratic institution building have contributed to meaningful forms of democratic progress.

\section{Institution building by democratic agents}

It may not be immediately obvious what such 'democratic practices' consist of in this case, since what we are characterising as democratic practices do not conform to many of the statecentric assumptions referred to above. It is therefore useful to begin by explaining the kinds of democratic institutions that we have in mind. Demands for democratization in this case have not targeted the creation of new forms of centralised global political power. Rather, such demands have focused on the democratization of the stable systems of social power that already exist, in the form of market and business institutions through which supply chain governance is organised in many manufacturing and agricultural sectors.

These relationships connect poor and politically marginalised workers with affluent and powerful consumer markets and corporate entities in the global north, through private systems of power encompassing the networked and contractual systems of 'supply chain governance'. ${ }^{59}$ Supply chain systems of decision making impact pervasively on the wellbeing and autonomy of individual workers and producers participating within transnational supply chains. These relationships have often been criticised as sites of significant democratic deficits, because of the large power disparities between supply chain participants, and absence of institutional channels for affected workers and producers to influence the decisions that affect their lives.

The democratic processes that have emerged in response to such concerns run contrary to the widespread belief that there currently exists no effective structure of power at the global level for democratic principles to 'go to work on' ${ }^{60}$ Rather, democratic institution building in this case is premised centrally on recognition of the transnational systems of effective power that are already being exercised through these global business and supply chain relationships. In

\footnotetext{
${ }^{59}$ G. Gereffi, 'A Commodity Chains Framework for Analyzing Global Industries', Available at: http://www.ids.ac.uk/ids/global/valchn.html, (1999).

${ }^{60}$ T. Nagel, 'The Problem of Global Justice'
} 
other words, processes of global democratization are being created in ways that 'track' existing transnational systems of organised power.

Democratisation of this kind has been pursued via several channels. First, it has been driven by demands to recognise the normatively public character of these kinds of economic power, and thus the entitlements of affected workers and producers to be recognised as democratic stakeholders (or members of a 'demos'). NGO and union led campaigns demanding strengthened 'corporate accountability' have contributed importantly to publicly identifying the significant autonomy-limiting power wielded by major retailers and brands over workers and producers, and promoting a corresponding acknowledgement of public responsibility on the part of corporate powerholders. ${ }^{61}$ These campaigns have depended importantly on the mobilisation of transnational coalitions of (mainly) non-state actors, bringing marginalised workers and producers together with relatively more powerful allies in the global north.

Such coalitions have developed the capacity to impose costs of various kinds on companies that fail to respond to demands for democratic entitlements of workers to be properly acknowledged. Consumer awareness and concern regarding working conditions in offshore factories has at various times been mobilised as a coercive weapon in support of campaigners' demands. Such sanctioning mechanisms operate both through direct consumer boycotts and deeper processes of socialisation manifested as reputational damage to company brands. ${ }^{62}$ To the extent that the value invested in the construction of corporate brands renders individual firms vulnerable to such forms of pressure, these strategies can offer effective means of sanctioning corporate decision makers.

Such forms of countervailing power can create significant incentives for powerful corporate decision makers to consent to the construction of transnational governance arrangements that make at least incremental contributions to the promotion of democratic values. These arrangements can then become institutionalised progressively in ways that enable them to endure, even beyond the usually limited lifespan of these transformative coalitions. One important way in which such values have been promoted is by establishment of a range of private governance arrangements that constrain corporate power within a principled system of transnational norms. These private governance arrangements have taken various forms. Private codes of conduct have been established by powerful transnational companies; by NGOs and 'ethical' businesses of various kinds, as in the case of the Fair Trade system; and by multi-stakeholder coalitions of actors, such as those participating in the Common Code for the Coffee Community or the Fair Labor Association.

Some of these transnational governance schemes have supported further efforts to strengthen the voice and democratic control of affected groups, by building mechanisms for stakeholder voice, representation and/or accountability into their internal governance arrangements. For example, some private governance schemes provide internal mechanisms through which stakeholders can directly communicate their preferences to decision makers, such as producer or worker representation provisions within governing bodies of the Fair Trade system, or

\footnotetext{
${ }^{61}$ K. Macdonald, 'Global Democracy for a Partially Joined-Up World: Toward a multi-level system of public power and democratic governance?', in D. Archibugi, M. Koenig-Archibugi and R. Marchetti (eds.) Global Democracy: Normative and Empirical Perspectives (Cambridge Cambridge University Press, 2011).

${ }^{62}$ V. Haufler, A Public Role for the Private Sector: Industry Self-Regulation in a Global Economy (Washington, DC: Carnegie Endowment for International Peace, 2001), R. O. Jenkins, Corporate codes of conduct : selfregulation in a global economy (Geneva: UNSRID, 2001), pp. ix, 35, J. G. Ruggie, 'global_governance.net: The Global Compact as Learning Network', Global Governance, 7 (2001), pp. 371-8.
} 
complaints mechanisms built into multi-stakeholder initiatives such as the Fair Labor Association or the Ethical Trading Initiative. More often, however, such communication has been facilitated via the involvement of northern intermediaries such as networks of labour unions and NGOs in the global north.

\section{Adapting democratic practices to obstacles encountered}

Building democratic institutions of these kinds has depended importantly on the capacity of transformative agents to work creatively around existing social barriers. Certainly, not all background social conditions have been hostile to the emergence of democratic practices. Participants in global supply chains share economic interests in generating income earning opportunities within an often harshly competitive economic environment. Moreover, it is possible to find examples in which transnational economic relationships have provided an institutional foundation for the gradual construction of shared identities between worker and consumers, such as those promoted by private regulatory schemes such as Fairtrade. ${ }^{63}$ Although transnational identities of this kind remain embryonic in both scope and strength, they demonstrate that the development of democratic norms need not require strong (and allencompassing) shared norms and identities.

Nevertheless, obstacles to the emergence and strengthening of these democratic practices have been significant. One important obstacle has resulted from the absence of effective centralised global governance arrangements equipped to curtail the exercise of transnational corporate power. To this extent, the success of democratic institution building has depended importantly on the capacity of democratic agents to devise strategies of democratic institutional design that are able to accommodate such conditions. In this instance, the institutions being created have been distinctively decentralised in form. This implies both that control over important dimensions of worker autonomy is diffused among a heterogeneous and decentralised range of actors and institutions, and that governance institutions designed to regulate such power are similarly multi-level and decentralised. By focusing on the decentred institutional structures of global supply chains as the primary target for democratisation, democratic agents have been able to adapt democratic practices to the features of prevailing social conditions, thereby increasing their 'fit' with background social conditions, and correspondingly their chances of success. Such creative strategies play an important role in explaining the distinctive forms that emerging democratic practices take in any given case.

Certainly, it has not been possible to navigate all hostile social conditions in this way. In important respects, structural constraints from background social conditions continue to limit the democratic potential of the practices that are emerging. There remains powerful resistance to recognition of these economic relationships as public in character, and therefore appropriate targets of democratisation. To the extent that economic relationships are not recognised as public in the first place, conflicts of social interest and power embedded within these relationships instead continue to be resolved through highly inegalitarian dynamics of economic power, within markets and other institutions of economic bargaining.

Moreover, those systems of transnational supply chain governance arrangements that have been created suffer major limitations with respect to their enforcement capacities. These

\footnotetext{
${ }^{63}$ K. Macdonald, 'Globalising justice within coffee supply chains? Fair Trade, Starbucks and the transformation of supply chain governance', Third World Quarterly: Special Issue on 'Beyond CSR? Business, Poverty and Social Justice', 25 (2007).
} 
result largely from the absence of coercive legal power backing up many of the private systems of transnational rules created to regulate these relationships. They are also a product of inconsistencies in the effectiveness of non-state sanctioning mechanisms across different business contexts. Weak collective action mechanisms among affected workers, and significant power disparities between many workers and producers and the 'intermediaries' helping them hold companies to account have also placed important limits on the democratic achievements of these institutional strategies. Moreover, decentralised democratic structures can generate problematic patterns of political inequality between different groups of democratic stakeholders. ${ }^{64}$

Nevertheless, the forms of gradual democratisation described above have increased democratic control over public decision-making processes within transnational supply chains in various ways. Most importantly, constraints have been placed on some of the most strongly autonomy limiting forms of corporate power, in response to demands from affected groups. As a result of the efforts of some corporate accountability initiatives, such as the US-based Worker Rights Consortium, worker representative structures within some enterprises have been strengthened, and voice in relation to standard setting and audit processes enabled (albeit weakly) in cases where previously it was absent. ${ }^{65}$ These practices are certainly far from anything we would call 'fully blown' democracy. Nevertheless, these modest yet meaningful accomplishments contribute significantly to processes of progressive global democratisation.

Clearly, progressive efforts to promote democratic values at both global and national levels have a huge distance yet to travel. Despite this, we have shown that it has been possible to establish meaningful democratic practices under highly inhospitable conditions at the global level. Moreover, we have argued that global democratization - although considerably less advanced than within most nation states - can nonetheless progress through very similar processes to those operating within national institutional systems. Although democracy at both global and national levels is undoubtedly very hard to achieve, meaningful democratic practices can emerge to the extent that social agents are able to work around prevailing constraints to build distinctive - albeit flawed - democratic institutions, adapted for the particular circumstances they encounter.

\section{Conclusions}

The central picture we have painted above is of the rather messy and uneven development of meaningful yet highly flawed and incomplete democratic practices at both the national and global levels. What are the lessons of this for debates about global democracy?

We have proposed that we can understand social practices as democratic in character to the extent that they contribute something meaningful towards protecting and promoting core democratic values (however imperfectly). The comparison we have presented between democratic practices at national and global levels has highlighted the significant constraints on the realisation of democratic values that such efforts face under pervasive social

\footnotetext{
${ }^{64}$ K. Macdonald, 'Global Democracy for a Partially Joined-Up World: Toward a multi-level system of public power and democratic governance?', in D. Archibugi, M. Koenig-Archibugi and R. Marchetti (eds.) Global Democracy: Normative and Empirical Perspectives (Cambridge Cambridge University Press, 2011).

${ }^{65}$ T. Connor, 'Re-writing the Rules: The anti-sweatshop movement; Nike, Reebok and Adidas' participation in voluntary labour regulation; and workers' rights to form trade unions and bargain collectively', in Department of Law (Newcastle: University of Newcastle, 2007).
} 
conditions of inequality and exclusion. Certainly, we have recognised that the democratic institutions documented in the case of global business regulation lack the capacity to protect democratic values to anything like the extent enabled by democratic institutions in Northern Ireland. Nevertheless, we have insisted that democratic debates are misguided to focus primarily on these kinds of static comparisons, which rank the democratic quality of actually existing democratic institutions against an idealised notion of democracy. Instead, we have suggested that we should focus on the more dynamic role of democratic values in underpinning imperatives for political mobilisation and progressive institutional reform. In this sense, we can understand a commitment to democratic values as demanding an ongoing struggle for social change: to counter power-differentials, exclusion and domination, and to enhance control by ordinary people over collective decisions in which they have an important stake. Processes of democratic institutional transformation in both Northern Ireland and in the case of global business regulation can teach us useful lessons about these processes, despite the very different degrees and kinds of democratic flaws present in each.

This shift of emphasis from the attainment of 'democracy' to the advancement of 'democratic practices' has important practical implications for how we judge the best ways to invest our political and intellectual energies. Unduly pessimistic assessments of global democratic prospects importantly underestimate the capacity of transformative democratic agency to develop creative strategic approaches to establish highly imperfect yet still meaningful democratic practices under inhospitable social conditions. Under some conditions, democratic practices can survive amidst high levels of social disagreement and conflict. Likewise, intense social power asymmetries can co-exist with democratic institutions under some conditions. What matters is not just the 'magnitude' of the social obstacles that exist, but rather the way institutions are able to adapt to prevailing conditions to create reasons for groups of individuals to accept the authority of political institutions. And this can be established in a great diversity of ways.

For this reason, conducting debates about global democratic reform with an image of a 'wellfunctioning national democracy' (or some variant) as the institutional reference point distorts our assessments of the prospects for meaningful democratic progress, playing into the agendas of what Goodin calls 'self-styled realists' who tend to be "too realistic - too quick to fold their highest moral aspirations in the face of obstacles that might well have been eminently surmountable, had only they tried". ${ }^{6}$

Viewing global democratic institutions instead through a non-ideal and institutionally open lens can help us to escape from this kind of binary way of thinking about the possibilities for global democratic reform, in which either global democracy in all its idealised and emancipatory glory can be realised, or all possibilities for democratic reform are completely foreclosed. Our discussions of potential global democratic practices should not be reliant on certainty about institutional configurations or the perfect encapsulation of democratic values in institutions. Rather, we should attempt to move the discussion beyond dichotomous understandings of possibilist versus impossibilist approaches.

If we see the pursuit of democracy as demanding a long and difficult struggle for social change and if we recognise the significant limitations that real democratic institutions in any context face, then this casts debates about the prospects for global democratic reform in a different light. Importantly, it poses new questions about the deployment of resources

${ }^{66}$ R. Goodin, 'Global Democracy: In the Beginning', p.178 
towards projects of social transformation. While democratic redemption might be out of reach, democratic transformation need not be. In practical terms, this suggests that advocates of global democratization should not wait until conditions are 'ready' before trying to promote the expansion and strengthening of democratic practices.

Of course, there remain important questions about priorities for the investment of transformative social energies and resources. As Miller has suggested, ${ }^{67}$ to the extent that global democracy is likely to be highly inegalitarian, elitist and narrow, the value of global democracy may be diminished, and the priority of pursuing global democracy vis a vis other goals (like strengthening international law, human rights or whatever) correspondingly lower. Nevertheless, such trade-offs rarely manifest as zero-sum games. Democratization at the global level will almost certainly continue to be uneven and multi-layered, as relatively more 'democratic' institutions interact with institutions of other kinds.

These are important strategic questions. But in judging them, we have tried to emphasise the importance of casting analogies between national and global democracy in sufficiently broad terms to be realistic about several aspects of democratic institution building. These include the imperfection of democratic institutions, the variety of democratic practices that - under different social conditions - can do useful democratic work, and the complex, contextdependent ways in which transformative social agency can work around otherwise unpropitious social conditions, to realise imperfect yet useful democratic practices.

${ }^{67}$ D. Miller, 'Against Global Democracy'. 


\section{University Library}

\section{- M M N E R VA A gateway to Melbourne's research publications}

Minerva Access is the Institutional Repository of The University of Melbourne

Author/s:

Little, A;Macdonald, K

Title:

Pathways to global democracy? Escaping the statist imaginary

Date:

2013-10-01

Citation:

Little, A. \& Macdonald, K. (2013). Pathways to global democracy? Escaping the statist imaginary. Review of International Studies, 39 (4), pp.789-813. https://doi.org/10.1017/ S0260210512000551.

Persistent Link:

http://hdl.handle.net/11343/91826 